\title{
Sensory attributes and Lipid oxidation of smoked lamb sausage formulated with passion fruit meal, potassium chloride and calcium chloride
}

\author{
Jonhny de Azevedo MAIA JUNIOR ${ }^{1,2 *}$ (D), Fábio da Costa HENRY'; Suzana Maria DELLA LUCIA; \\ Alexandre Cristiano SANTOS JUNIOR ${ }^{1}$; Natália de Oliveira CABRAL ${ }^{1}$; Célia Raquel QUIRINI ${ }^{1}$; \\ Felipe Roberto Amaral Ferreira VALLE ${ }^{4}$
}

\begin{abstract}
This study evaluated the sensory attributes and lipid peroxidation of smoked lamb sausage prepared with passion fruit meal, potassium chloride and calcium chloride. The samples were produced and smoked at Instituto Federal do Espírito Santo, where they were kept vacuum packed and frozen until laboratory analysis. The formulations with passion fruit meal presented lower weight loss by smoking. No microbiological growth was detected in the 90-day study period. Formulation 1 was the best in the attributes color, aroma, flavor, texture, overall impression and purchase intention. The use of passion fruit meal to replace fat, potassium chloride and calcium chloride did not affect oxidation of the product during the study period. The addition of passion fruit meal, potassium chloride and calcium chloride to smoked lamb sausage, especially in Formulation 1, produced the best results and the levels of these ingredients did not interfere in oxidation.
\end{abstract}

Keywords: reduced fat; low sodium; loss by smoking; microbiology; TBARS.

Practical Application: This article is relevant for the food industry because it investigates sensory attributes and lipid oxidation of smoked lamb sausage formulated with passion fruit meal, potassium chloride and calcium chloride. The data obtained show that this product can be included in the diet of patients with systemic hypertension. Additionally, the data may be important for future research in food science.

\section{Introduction}

Food fibers have important physiological effects and are used to enhance many processed food products. Their levels of polysaccharides, lignin, oligosaccharides and resistant starch, among other components, are responsible for various interesting properties of foods (Souza et al., 2008). In this context, one of the main concerns in the food industry in recent years is the development of products to meet the demands of various consumer segments, like people with hypertension and/or obesity, who should control sodium and fat levels in foods (He et al., 2005; Galvan et al., 2011).

Fiber plays an important role in the meat product industry. This material has interesting technological properties that improve texture, reduce loss by cooking, and lower production costs. Also, fiber can be successfully used as a fat substitute (Aleson-Carbonell et al., 2004).

The market for encased meat products is growing steadily. These products make up a considerable share of diets in Brazil, and sausage is the most widely produced and sold encased meat product in the country. Low production costs make it easily available to all segments of the retail food market. In addition to meat, its basic raw material, the formulation of sausage also contains salt, as a source of sodium, and fat.
This position in the market has motivated researchers to investigate the effect of salt reduction on foods, when sodium chloride $(\mathrm{NaCl})$ is replaced by potassium chloride $(\mathrm{KCl})$ or a complex of salts ( $\mathrm{KCl}$ and calcium chloride, $\mathrm{CaCl}_{2}$ ) (Bernardi \& Roman, 2011; Horita et al., 2011; Vidal et al., 2019). The replacement of fat by products with similar characteristics is a viable alternative. Passion fruit meal (PFM), a byproduct of fruit processing, is a potential source of fiber, with good water retention capacity and interesting antioxidant and antibacterial effects. The benefits of PFM to health include the prevention of diseases like heart conditions and diabetes, due to the high levels of bioactive compounds such as vitamins, minerals, antioxidants, polyphenols, and fiber (López-Vargas et al., 2013). In this context, studies using dietary fiber as antioxidant and antimicrobial agents in meat products with high content of mechanically separated meat (Horita et al., 2016), as well as inclusion of dietary fiber to replace fat (Maia et al., 2017), have presented excellent results.

But skin-encased products have short shelf lives, and the lipids they contain may undergo oxidation. Lipid oxidation is one of the main reactions that determine the end of shelf life of skin-encased products. The process affects the nutritional 
and sensory attributes of these products, and the level of thiobarbituric acid-reactive substances (TBARS index) is the main parameter used to detected the degree of lipid peroxidation (Almeida et al., 2015).

The present study evaluated the sensory attributes and lipid peroxidation of smoked lamb sausage prepared with $\mathrm{PFM}, \mathrm{KCl}$ and $\mathrm{CaCl}_{2}$.

\section{Materials and methods}

The sensory analysis of smoked lamb sausages was carried out in the Sensory Analysis Laboratory, Department of Food Engineering, Espírito Santo Federal University (UFES). The microbiological analysis of samples was conducted in the Microbiology Laboratory, and weight loss from smoking was evaluated in the Meat Processing Laboratory, both associated with Federal Institute of Espírito Santo (IFES), Alegre Campus. Also, lipid oxidation was analyzed in the Food Technology Laboratory of Norte Fluminense State University (UENF) in the state of Rio de Janeiro.

\subsection{Samples}

The samples were prepared using frozen lamb shoulders imported from a meat producer in the municipality of Paso de Los Toros, Uruguay. The samples were appropriately transported to IFES and stored in a freezer at $-18^{\circ} \mathrm{C}$. Before preparation, meat was thawed slowly under refrigeration at $2{ }^{\circ} \mathrm{C}$ to $4{ }^{\circ} \mathrm{C}$ and deboned.

Passion fruit meal was purchased at a local shop. The other ingredients and additives were bought at shops specialized in goods for the manufacture of encased meat products.

After thawing, lamb and fat were each diced finely and then ground and weighed. Fat was added to lamb, followed by seasonings and additives. Passion fruit meal was the last ingredient added, to inhibit the formation of lumps. All ingredients were thoroughly mixed. The lamb mix obtained was encased in natural pig intestines obtained from IFES using a a manual $36 \mathrm{~mm}$ sausage funnel.

The sausages obtained were smoked for approximately $3 \mathrm{~h}$, until temperature in the middle of a sausage was $75^{\circ} \mathrm{C}$. Then they were removed from the smoker and appropriately stored to cool naturally for $24 \mathrm{~h}$, vacuum packed, labeled, and stored in a freezer at $-18^{\circ} \mathrm{C}$ for later analysis.

We prepared four formulations, one of which was used as control. These formulations were defined in five pilot tests to evaluate the acceptable decrease in levels of fat and sodium. The composition of sausage formulations and the percent decrease in fat and sodium levels in the formulations are shown in Table 1.

Fat was partly replaced by PFM according to Oliveira \& Resende (2012), containing on average $26.4 \%$ pectin. Sodium levels were decreased by replacing $\mathrm{NaCl}$ with $\mathrm{KCl}$ and a mixture of $\mathrm{KCl}$ and $\mathrm{CaCl}_{2}$.

\subsection{Weight loss by smoking}

After preparation, samples were smoked for approximately $3 \mathrm{~h}$ until temperature in the middle of the sausage reached $75^{\circ} \mathrm{C}$, when they were removed from the smoker and appropriately stored for $24 \mathrm{~h}$, to cool naturally. Samples were weighed again, and the loss by smoking was calculated using Equation 1, as recommended by Tobin et al. (2012).

Loss by smoking $(\%)=\left(\begin{array}{l}\text { weight after smoking - } \\ \text { weight before smoking / } \\ \text { weight before smoking }\end{array}\right) \times 100$

\subsection{Microbiological analyses}

Sausages were analyzed according to Silva et al. (2010). The results were compared with the standards listed in RDC 12 from the National Sanitary Surveillance Agency, ANVISA (Brasil, 2001) for coliforms at $45^{\circ} \mathrm{C}\left(10^{3}\right)$, coagulase-positive (CP) Staphylococcus (negative) and Salmonella (negative).

Table 1. Composition of the four smoked lamb sausage formulations used in this study and percent decrease in fat and NaCl levels in smoked lamb sausage.

\begin{tabular}{|c|c|c|c|c|}
\hline \multirow{2}{*}{ Ingredient } & Control & $\mathrm{F} 1$ & F2 & $\mathrm{F} 3$ \\
\hline & \multicolumn{4}{|c|}{$\%$} \\
\hline Meat & 75.66 & 75.66 & 75.66 & 75.66 \\
\hline Fat & 20.00 & 19.00 & 18.00 & 17.00 \\
\hline $\mathrm{NaCl}^{1}$ & 2.20 & 1.65 & 1.10 & 0.55 \\
\hline $\mathrm{KCl}^{2}$ & 0.00 & 0.275 & 0.55 & 0.55 \\
\hline $\mathrm{CaCl}_{2}^{2}$ & 0.00 & 0.275 & 0.55 & 1.10 \\
\hline Sugar $^{3}$ & 0.095 & 0.095 & 0.095 & 0.095 \\
\hline Water & 2.00 & 2.00 & 2.00 & 2.00 \\
\hline Passion fruit meal & 0.00 & 1.00 & 2.00 & 3.00 \\
\hline Salt $^{4}$ & 0.015 & 0.015 & 0.015 & 0.015 \\
\hline Sodium erythorbate ${ }^{5}$ & 0.025 & 0.025 & 0.025 & 0.025 \\
\hline \multicolumn{5}{|c|}{ Decrease } \\
\hline Fat & 0 & 1 & 2 & 3 \\
\hline $\mathrm{NaCl}$ & 0 & 25 & 50 & 75 \\
\hline
\end{tabular}

${ }^{1}$ Kitchen salt, Cisne ${ }^{\circledast} ;{ }^{2}$ P.A,. Merck ${ }^{\circledast} ;{ }^{3}$ Muscovado Sugar, União ${ }^{\circledast} ;{ }^{4}$ Cura Kura K007, Doremus ${ }^{\circledR} ;{ }^{5}$ Antioxidant, Griffith ${ }^{\circledR}$. 


\subsection{Sensory analysis}

An acceptance test with hedonic scale was used for the sensorial evaluation, using a scale of 9 points $(9=$ like extremely, $5=$ neither like nor dislike, and 1 = dislike extremely), commonly used for meat evaluation (Torrico et al., 2018). The intention to purchase was also estimated, with a scale of 5 points (5: would certainly buy; 3 : maybe would buy; 1 : would certainly not buy), to assess consumers' intent in relation to the product (Guimarães et al., 2018).

The smoked lamb sausages were analyzed for sensory attributes by 60 untrained participants ( 40 women and 20 men, aged between 18 and 45 years), who were recruited among students and staff members of UFES, Alegre Campus. Briefly, $1 \mathrm{~cm}$-thick slices were cut starting from the middle of the sausage and cooked in an electric oven at $180{ }^{\circ} \mathrm{C}$ for $10 \mathrm{~min}$.

Two slices of cooked sausage of each formulation were placed in labeled plates and randomly presented to participants. Water at room temperature was also available. Participants were given an evaluation form with the nine-point hedonic scale to assess color, aroma, flavor, texture and overall impression. A five-point purchase intention scale was also in the evaluation form.

Sensory analysis was conducted after microbiological evaluation, which showed that sausage samples met the standards defined in RDC 12/2001 (Brasil, 2001) and were approved for consumption by the university's ethics committee (authorization no. 684.829).

\subsection{Lipid oxidation}

Lipid oxidation was based on the quantification of TBARS according to Vyncke (1970) and modified by Sorensen \& Jorgensen (1996).

Smoked lamb sausages were homogenized. Then, $5 \mathrm{~g}$ samples were retrieved from the sausage filling and placed in a $30 \times 200 \mathrm{~mm}$ brimless round-bottom glass test tube. Next, $20 \mathrm{~mL}$ of $5 \%$ trichloroacetic acid (TCA) and $1 \mathrm{~mL}$ of $0.15 \%$ butylhydroxytoluene (BHT), a synthetic antioxidant, were added to the tubes. The material was processed in a homogenizer (Ultra-Turrax, Ika) for $60 \mathrm{~s}$. Then the material was strained through qualitative filter paper $(12.5 \mathrm{~mm})$ into a $50 \mathrm{~mL}$ volumetric flask. The volume was completed with $5 \%$ TCA and $5 \mathrm{~mL}$ aliquots were transferred to test tubes. After that, $5 \mathrm{~mL}$ of thiobarbituric acid $0.08 \mathrm{M}$ was added to the tubes, which were then incubated in a double bath with simmering water for $40 \mathrm{~min}$, to allow the color complex to form. The tubes were then placed under a stream of water to cool down to room temperature. The contents were analyzed in a spectrophotometer (UV-5100, Kasuaki) at $532 \mathrm{~nm}$. The results were subtracted from the values obtained for a blank sample.

We used the standard 1,1,3,3-tetraethoxypropane (TEP) curve to find the TBARS values. The curve was plotted with concentration and absorbance on the $\mathrm{x}$ and $\mathrm{y}$ axes, respectively. The concentration of TBARS in samples was calculated by linear regression. The values were expressed as mg of malondialdehyde (MDA)/kg of sample. The analyses were carried out in triplicate using samples stored for three experimental times: 0, 45, and 90 days in cold rooms at $-18^{\circ} \mathrm{C}$.

\subsection{Statistical analyses}

Weight loss by smoking and lipid oxidation data were submitted to analysis of variance (ANOVA) and the Student-Newman-Keuls test at $5 \%$ probability, using the statistical software SAS Institute (2009) version 9.3. Sensory analysis data were also submitted to ANOVA, followed by the Tukey test at $5 \%$ probability with the same software.

\section{Results and discussion}

\subsection{Weight loss by smoking}

The results of the analysis of loss by smoking are given in Table 2.

Due to the paucity of published data on loss by smoking, we compared the results obtained with loss by cooking findings. It is assumed that smoking is a cooking process that uses smoke as heating medium.

No statistically significant difference was observed in loss by smoking between the control sample and F1, and between F2 and F3. However, control and F1 differed significantly $(\mathrm{P}<0.05)$ from F2 and F3.

Loss by smoking was lower in the formulations containing higher PFM concentrations in lieu of fat (2\% and 3\% replacement of fat, F2 and F3, respectively). As described by Souza et al. (2008) in a study of the functional properties of PFM, the material was rich in fiber and exhibited good water retention capacity. Yalinkiliç et al. (2012) analyzed nine samples of Sucuk, a dried and fermented sausage popular in Turkey. Samples were prepared with various levels of fat and orange fiber, which was found to reduce loss by cooking. Lemon pericarp has been shown to have the same effect in dry, cured sausages (Aleson-Carbonell et al., 2004). Interestingly, in a study of the addition of lemon pericarp to hamburgers, the authors observed that high concentrations of the ingredient decreased loss by cooking due to the fact that water and fat molecules bind to the fiber.

Similar findings have been observed in previous investigations that confirmed the gelatinization, stabilization, and thickening properties of PFM (Maia et al., 2017).

Likewise, the formulations that presented lower $\mathrm{NaCl}$ concentration (F2 and F3) presented lower loss due to smoking, because this concentration is related to the ionic strength, whereby a reduction of $\mathrm{NaCl}$ leads to a lower extraction of the myofibrillar proteins responsible for emulsification, gelatinization and water retention capacity of the meat product. In other words, when $\mathrm{NaCl}$ is reduced, the amount of protein extracted can also decline along with the water retention, reflecting the final characteristics of the product (Horita et al., 2011). The same authors reported

Table 2. Loss by smoking of lamb sausage.

\begin{tabular}{cc}
\hline & Loss by smoking $(\%)$ \\
\hline Control & $14.70^{\mathrm{a}} \pm 0.51$ \\
F1 & $13.05^{\mathrm{a}} \pm 0.22$ \\
F2 & $10.75^{\mathrm{b}} \pm 1.62$ \\
F3 & $11.15^{\mathrm{b}} \pm 0.07$ \\
\hline
\end{tabular}

${ }^{\mathrm{ab}}$ Means followed by different letters differ by the Student-Newman-Keuls test $(\mathrm{P}<0.05)$. 
that studies using chlorinated salts $\left(\mathrm{KCl}\right.$ and $\left.\mathrm{CaCl}_{2}\right)$ in partial replacement of $\mathrm{NaCl}$ in mortadella sausage revealed a significant increase in product's hardness due to gel formation, similar to the results found in the present study.

\subsection{Microbiological analyses}

The results of the microbiological analyses of smoked lamb sausages are shown in Table 3.

The negative results for coliforms at $45^{\circ} \mathrm{C}, \mathrm{CP}$ Staphylococcus/g, and Salmonella sp. $/ 25 \mathrm{~g}$ demonstrate the safety of the sausage samples analyzed during the 90 -day period. The product met the Brazilian standards for safe food consumption (Brasil, 2001). These findings reveal the efficacy of the hygiene practices followed during preparation and storage. The good quality of raw materials and chemicals used in formulations and the efficiency of the smoking and packaging processes also contributed to these results. In addition, according to López-Vargas et al. (2013), the potential bactericidal action of PFM may also have helped produce an excellent, microorganism-free encased meat product.

\subsection{Sensory analyses}

The sensory analyses of color, aroma, flavor, texture, and overall impression of samples of smoked lamb sausages are shown in Figure 1.

The results show that the control and F1 formulations were well accepted by participants concerning all attributes assessed. Formulation F2 had good acceptance in terms of color and aroma. The acceptability indexes of the attributes evaluated were all above 7. According to Dutcosky (2011), an acceptability index of 7 is the maximum a product can reach in order to be considered of good acceptability in terms of sensory attributes. The formulations with best acceptability in all attributes were the ones produced with the higher fat levels: control, with $20 \%$, and F1, with $19 \%$ fat. In a study of low-fat sausages prepared with tambaqui meat (Colossoma macropomum), Sleder et al. (2015) observed that acceptability decreased with fat lower fat levels. Fat plays an important role in acceptability of meat products, and has been associated with flavor, tenderness and succulence (Juárez et al., 2012).

From the point of view of the inclusion of $\mathrm{KCl}$ and $\mathrm{CaCL}_{2}$, there was a reduction in the acceptance of the formulations that had the highest reduction of $\mathrm{NaCl}$ ( $\mathrm{F} 2$ and F3), since the inclusion of these salts can lead to technological and sensorial problems in the product, such as overly salty taste, accentuation of bitter taste and presence of metallic and astringent flavors. This also changes the texture and color of this product, due to the action of different cations on the enzymatic activity during the curing and drying process (Otto et al., 2014). With the increase in the concentration of chloride salts $\left(\mathrm{KCl}\right.$ and $\left.\mathrm{CaCl}_{2}\right)$, there is a greater rejection of the consumers, as demonstrated by the study carried out by Rech (2010) with Italian salamis formulated with $\mathrm{CaCl}_{2}$ and $\mathrm{NaCl}$, as found in our study.

Concerning flavor, no statistically significant difference $(P>0.05)$ was observed between control and F1. However, the other treatments differed significantly $(P \leq 0.05)$ due to the lower fat amounts used and higher proportion of PFM. Previous research has indicated the important role of fat in acceptability of meat products (Juárez et al., 2012).

Texture did not differ significantly $(\mathrm{P}>0.05)$ between the control and $\mathrm{F} 1$ formulations. A significant difference $(\mathrm{P} \leq 0.05)$ was observed between the other treatments. Horita et al. (2011) observed that mortadella prepared with lower amounts of fat and $\mathrm{NaCl}$ had increased texture values, which was also observed in the present study for smoked lamb sausages. The reduction of fat increases hardness, since the ingredient is associated with the development of emulsions. In turn, $\mathrm{NaCl}$ produces the ionic forces required for dissolution and extraction of myofibril proteins responsible for emulsification, gelatinization, water retention and other properties. An identical conclusion was found in the analysis of mortadella prepared with tilapia and wheat flour (Mélo et al., 2011). Research has also shown that hardness of meat

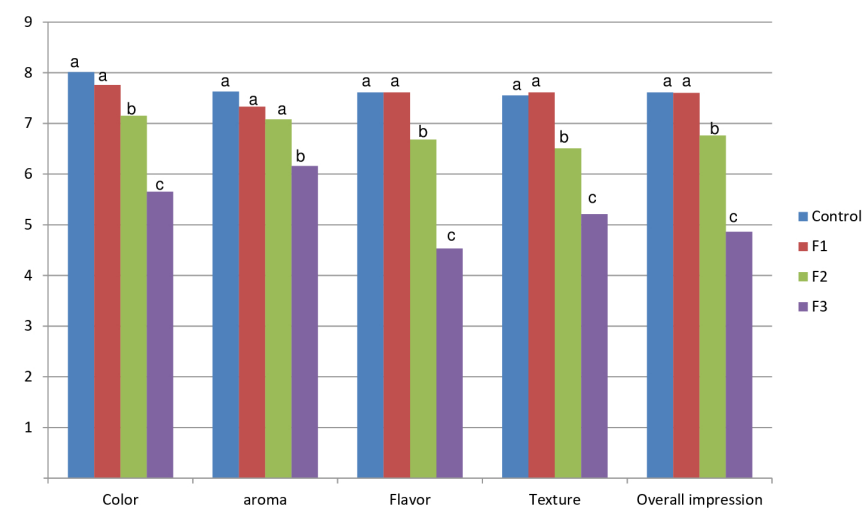

Figure 1. Results of the sensory acceptance of smoked lamb sausage formulations. Means followed by the same letter in the same attribute do not differ by Tukey test at $5 \%$ probability.

Table 3. Results of the microbiological analyses of smoked lamb sausages.

\begin{tabular}{|c|c|c|c|c|c|c|c|c|c|}
\hline \multirow{2}{*}{ Days } & \multicolumn{3}{|c|}{ Coliforms NMP/g) } & \multicolumn{3}{|c|}{ Staphylococcus } & \multicolumn{3}{|c|}{ Salmonella } \\
\hline & 0 & 45 & 90 & 0 & 45 & 90 & 0 & 45 & 90 \\
\hline Control & $<3.0$ & $<3.0$ & $<3.0$ & Negative & Negative & Negative & Negative & Negative & Negative \\
\hline F1 & $<3.0$ & $<3.0$ & $<3.0$ & Negative & Negative & Negative & Negative & Negative & Negative \\
\hline F2 & $<3.0$ & $<3.0$ & $<3.0$ & Negative & Negative & Negative & Negative & Negative & Negative \\
\hline F3 & $<3.0$ & $<3.0$ & $<3.0$ & Negative & Negative & Negative & Negative & Negative & Negative \\
\hline $\begin{array}{c}\text { Standard } \\
\text { RDC 12/01 }\end{array}$ & & $<3.0$ & & & Negative & & & Negative & \\
\hline
\end{tabular}


products is associated with higher levels of fiber (Cardoso et al., 2013), which was also observed in the present study.

The overall impression did not vary significantly $(\mathrm{P}>0.05)$ between control and F1. But as above, the other formulations differed significantly $(\mathrm{P} \leq 0.05)$. This is explained by the gradual decrease in fat and $\mathrm{NaCl}$ levels used, reducing attractiveness of the product to consumers, as also discussed by Sleder et al. (2015) and Horita et al. (2011).

Figure 2 shows the purchase intention data.

Concerning purchase intentions, scores 4 or 5,3 , and 1 or 2 were attributed to 'acceptance, 'indifference, and 'rejection', respectively. Acceptance values of control and F1 were higher, reaching the 'would probably buy' score. F2 had the score 'maybe would buy', while F3 had the highest rejection score, 'would probably not buy' (Guerra et al., 2012).

It is important to emphasize that more studies are needed to complement the sensorial evaluations of the formulations studied. For example, descriptive sensorial methods, which provide the sensorial description of product attributes, would be very interesting to trace the sensorial profile of sausages, since the formulations developed have different characteristics than the control formulation. Recent sensory methods have been based on consumer perceptions to describe the products, generating very interesting data, since they do not employ trained evaluators, but rather consumers themselves. In addition to this, we can mention the Pivot Profile, Check-all-that-apply, Temporal Check-all-that-apply, Projective Mapping, Progressive Profile

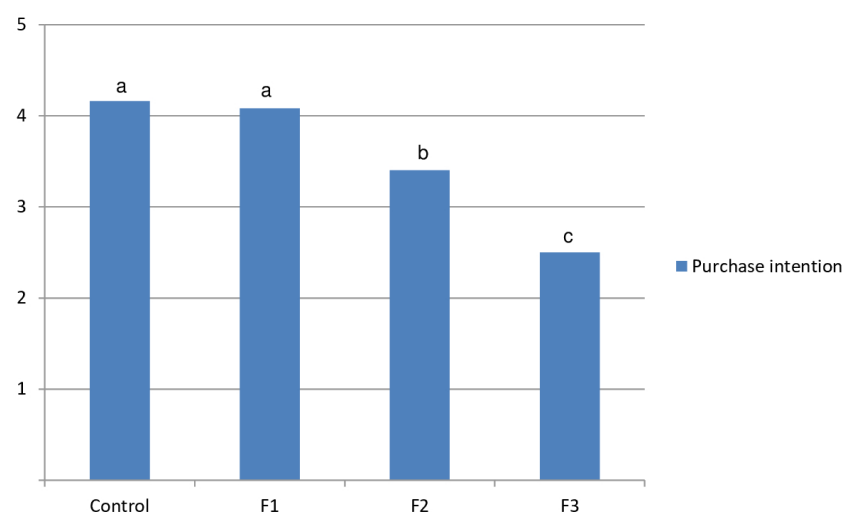

Figure 2. Results of the purchase intention based on sensory analysis of smoked lamb sausage formulations. Means followed by the same letter in the same attribute do not differ by the Tukey test at $5 \%$ probability. and Temporal Dominance of Sensation methods (Cruz et al., 2013; Esmerino et al., 2017a; Esmerino et al., 2017b). Projective techniques such as the Free Word Association and the Haire's shopping list (Pinto et al., 2018) can also be applied to understand consumers' perceptions, thoughts and beliefs regarding products, since they were developed with partial substitution of sodium and of fat.

\subsection{Lipid oxidation}

The mean TBARS values expressed as $\mathrm{mg}$ MDA $/ \mathrm{kg}$ for smoked lamb sausage are shown in Table 4.

The most common method to evaluate lipid oxidation in meat and meat products is the quantification of TBARS. According to Gray \& Pearson (1987), lipid oxidation in meat products starts when TBARS levels are between 0.5 and $2.0 \mathrm{mg} \mathrm{MDA} / \mathrm{kg}$ of sample. The addition of PFM to replace fat, $\mathrm{KCl}$ and $\mathrm{CaCl}_{2}$ did not influence TBARS, with no significant difference $(\mathrm{P}>0.05)$ between formulations during storage. Nevertheless, TBARS values varied along the experimental period, decreasing from $0.03 \mathrm{mg} \mathrm{MDA} / \mathrm{kg}$ of sample to $0.01 \mathrm{mg} \mathrm{MDA} / \mathrm{kg}$ of sample on days 0 and 90 , respectively. This may have been due to the degradation of MDA to other compounds during vacuum storage and the action of phenols generated in the smoking process. Almeida et al. (2015) observed that TBARS values of sausage prepared with the extract of the Brazilian grape bark, Plinia cauliflora, differed significantly between day 0 and day 35 , when their study period finished. The present results confirm those findings, since no increase in oxidation was observed. Rather, we found relatively constant TBARS values that mildly decreased towards the end of the experiment (90 days). According to Almeida et al. (2015), lower lipid oxidation values are due to the presence of phenols in the bark of Plinia cauliflora. Also, according to Radha Krishnan et al. (2014), as cited by Almeida et al. (2015), the antioxidant power of phenols is associated with the hydroxyl group attached to the aromatic ring, which is able to donate electrons with hydrogen atoms that neutralize free radicals. This mechanism blocks degradation of the oxidative form, as observed for MDA.

The results of the present study confirm published findings. Previous research has shown that PFM is very effective to reduce lipid oxidation or induce its stasis, since it has antioxidant potential (López-Vargas et al., 2013). Also, Alejandre et al. (2016) investigated the effect of linseed oil and carrageenan glue to replace fat in salami. The authors reported that the ingredients did not influence TBARS levels of samples. Another key point in this study was the concomitant use of other salts, sodium

Table 4. The mean TBARS values expressed as mg MDA/kg for smoked lamb sausage.

\begin{tabular}{|c|c|c|c|}
\hline & \multicolumn{3}{|c|}{ TBARS (days) } \\
\hline & 0 & 45 & 90 \\
\hline Control & ${ }^{\mathrm{A}} 0.016 \pm 0.01^{\mathrm{a}}$ & ${ }^{\mathrm{A}} 0.027 \pm 0.02^{\mathrm{a}}$ & ${ }^{\mathrm{A}} 0.010 \pm 0.021^{\mathrm{a}}$ \\
\hline F1 & ${ }^{\mathrm{A}} 0.042 \pm 0.04^{\mathrm{a}}$ & ${ }^{\mathrm{A}} 0.029 \pm 0.02^{\mathrm{a}}$ & ${ }^{\mathrm{A}} 0.005 \pm 0.01^{\mathrm{a}}$ \\
\hline F3 & ${ }^{\mathrm{A}} 0.018 \pm 0.02^{\mathrm{a}}$ & ${ }^{\mathrm{A}} 0.041 \pm 0.03^{\mathrm{a}}$ & ${ }^{\mathrm{A}} 0.012 \pm 0.01^{\mathrm{a}}$ \\
\hline
\end{tabular}

Means in the same row followed by different uppercase letters differ $(\mathrm{P}<0.05)$ by the Student-Newman-Keuls test; and means in the same column followed by different lowercase letters do not differ $(\mathrm{P}>0.05)$ by the same test. 
nitrite and sodium erythorbate, which are essential in curing processes, acting as antioxidants. Previous studies with salami showed that the interaction between these salts induces a mild decrease in TBARS.

\section{Acknowledgements}

We are grateful to the Brazilian agency Fundação de Amparo à Pesquisa do Estado do Rio de Janeiro (FAPERJ).

\section{References}

Alejandre, M., Poyato, C., Ansorena, D., \& Astiasarán, I. (2016). Linseed oil gelled emulsion: A successful fat replacer in dry fermented sausages. Meat Science, 121, 107-113. http://dx.doi.org/10.1016/j. meatsci.2016.05.010. PMid:27300155.

Aleson-Carbonell, L., Fernadez-Lopez, J., \& Sendra, E. (2004). Quality characteristics of a no-fermented dry cured sausage formulated with lemon albedo. Journal of the Science of Food and Agriculture, 84(15), 2077-2084. http://dx.doi.org/10.1002/jsfa.1912.

Almeida, P. L., Lima, S. N., Costa, L. L., Oliveira, C. C., Damasceno, K. A., Santos, B. A., \& Campagnol, P. B. (2015). Effect of jabuticaba peel extrct on lipid oxidation, microbial stability and sensory properties of Bologna-type sausages during refrigerated storage. Meat Science, 110, 9-10. http://dx.doi.org/10.1016/j.meatsci.2015.06.012. PMid:26156583.

Bernardi, D. M., \& Roman, J. A. (2011). Caracterização sensorial de linguiça Toscana com baixo teor de sódio e análise do consumo de carne suína e derivados na região Oeste do Paraná. Boletim CEPPA, 29(1), 33-42. http://dx.doi.org/10.5380/cep.v29i1.22747.

Brasil. Agência Nacional de Vigilância Sanitária. (2001, January 2). Regulamento técnico sobre padrões microbiológicos para alimentos (RDC no 12, de 2 de janeiro de 2001). Diário Oficial [da] República Federativa do Brasil. Brasília. Retrieved from http://portal.anvisa. gov.br/documents/33880/2568070/RDC_12_2001.pdf/15ffddf63767-4527-bfac-740a0400829b.

Cardoso, J. B. N., Henry, F. C., Almeida, S. B., Ferreira, K. S., \& Ladeira, S. A. (2013). Characterization of cooked ham contaning pectin and potassium chloride. Journal of Food Processing and Preservation, 37(2), 100-108. http://dx.doi.org/10.1111/j.1745-4549.2011.00625.x.

Cruz, A. G., Cadena, R. S., Castro, W. F., Esmerino, E. A., Rodrigues, J. B., Gaze, L., Faria, J. A. F., Freitas, M. Q., Deliza, R., \& Bolini, H. M. A. (2013). Consumer perception of probiotic yogurt: Performance of check all that apply (CATA), projective mapping, sorting and intensity scale. Food Research International, 54(1), 601-610. http:// dx.doi.org/10.1016/j.foodres.2013.07.056.

Dutcosky, S. D. (2011). Análise sensorial de alimentos. Curitiba: Editora Universitária Champagnat.

Esmerino, E. A., Castura, J. C., Ferraz, J. P., Tavares, E. R. Fo, Silva, R., Cruz, A. G., Freitas, M. Q., \& Bolini, H. M. A. (2017b). Dynamic profiling of different ready-to-drink fermented dairy products: A comparative study using Temporal Check-All-That-Apply (TCATA), Temporal Dominance of Sensations (TDS) and Progressive Profile (PP). Food Research International, 101, 249-258. http://dx.doi. org/10.1016/j.foodres.2017.09.012. PMid:28941691.

Esmerino, E. A., Tavares, E. R. Fo, Thomas Carr, B., Ferraz, J. P., Silva, H. L. A., Pinto, L. P. F., Freitas, M. Q., Cruz, A. G., \& Bolini, H. M. A. (2017a). Consumer-based product characterization using Pivot Profile, Projective Mapping and Check-all-that-apply (CATA): A comparative case with Greek yogurt samples. Food Research
International, 99(Pt 1), 375-384. http://dx.doi.org/10.1016/j. foodres.2017.06.001. PMid:28784495.

Galvan, A. P., Rosa, G., Back, J., Lima, D. P., \& Corso, M. P. (2011). Aceitação sensorial de linguiça Tipo Toscana com teor reduzido de gordura e adição de pectina e inulina. Revista Ciências Exatas e Naturais, 13(3), 383-398.

Gray, J. I., \& Pearson, A. M. (1987). Rancidity and warmed-over flavor. In A. M. Pearson \& T. R. Duston (Eds.), Restructured meat and poultry products, advances in meat research (pp. 221-269). New York: Van Nostrand Reinhold.

Guerra, I. C. D., Meireles, B. R. L. A., Félex, S. S. S., Conceição, M. L., Souza, E. L., Benevide, S. D., \& Madruga, M. S. (2012). Carne de ovinos de descarte na elaboração de mortadelas com diferentes teores de gordura suína. Ciência Rural, 42(12), 2288-2294. http:// dx.doi.org/10.1590/S0103-84782012005000113.

Guimarães, J. L. B., Calixto, F. A. A., Keller, L. A. M., Silva, E., Furtado, A. A. L., \& Mesquita, F. M. (2018). Development of a low commercial value fish-sausage from the fish trawling "mix" category. Food Science Technology, 39(Suppl. 1), 1-7.

He, F. J., Markandu, N. D., \& Mac Gregor, A. (2005). Modest Salt Reduction Lowers Blood Pressure in Isolated Systolic Hypertension and Combined Hypertension. Hypertension, 46(1), 66-70. http:// dx.doi.org/10.1161/01.HYP.0000171474.84969.7a. PMid:15956111.

Horita, C. N., Farías-Campomanes, A. M., Barbosa, T. S., Esmerino, E. A., Gomes da Cruz, A., \& Bolini, H. M. A. (2016). The antimicrobial, antioxidant and sensory properties of garlic and its derivatives in Brazilian low-sodium frankfurters along shelf-life. Food Research International, 84, 1-8. http://dx.doi.org/10.1016/j.foodres.2016.02.006.

Horita, C. N., Morgano, M. A., Celeghini, R. M., \& Pollonio, M. A (2011). Physico-chemical and sensorial properties of reduced-fat mortadella prepared wuth blends od calcium, magnesium and potassium chloride as partial substitutes for sodium chloride. Meat Science, 89(4), 426-433. http://dx.doi.org/10.1016/j.meatsci.2011.05.010. PMid:21645975.

Juárez, M., Lopez-Campos, O., Dungan, M., Utarro, B., \& Aalhus, J. (2012). Beef texture and juiciness. In Y. H. Hui, Handbook of meat and meat processing (pp. 177-188). New York: CRC Press. http:// dx.doi.org/10.1201/b11479-13.

López-Vargas, J. H., Fernández-López, J., Pérez-Álvarez, J. A., \& ViudaMortos, M. (2013). Chemical, physico-chemical, technological, antibacterial and antioxidant properties of dietary fiber powder obtained from yellow passion fruit (Passiflora edulis var. flavicarpa) co-products. Food Research International, 51(2), 756-763. http:// dx.doi.org/10.1016/j.foodres.2013.01.055.

Maia, J. A. Jr, Henry, F. C., Valle, F. R. F. A., Santos, A. C. Jr, Regis, S. A., Souza, Y. L., \& Quirini, C. R. (2017). Physicochemical, characteristics of low-fat, low-salt fresh lamb sausage. Revista Electrónica de Veterinaria, 18(12), 1-12.

Mélo, H. M. G., Moreeira, R. T., Dálmas, O. S., Maciel, M. I. S., Barbosa, J. M., \& Mendes, E. S. (2011). Viabilidade da utilização da Carne Mecanicamente Separada (CMS) de tilápia na elaboração de um produto tipo "Mortadela". Revista ARS Veterinaria, 27, 22-29.

Oliveira, E. M. S., \& Resende, E. D. (2012). Yield of albedo flour and pectin content in the rind of yellow passion fruit. Food Science and Technology, 32(3), 492-498. http://dx.doi.org/10.1590/S010120612012005000067.

Otto, S. M., Serbai, D., \& Novello, D. (2014). Sensory acceptability of soup prepared with different salts sodium chloride substitutes. Revista do Instituto Adolfo Lutz, 73, 226-232. 
Pinto, L. P. F., Silva, H. L. A., Kuriya, S. P., Maçaira, P. M., Olivira, F. L. C., Cruz, A. G., Esmerino, E. A., \& Freitas, M. Q. (2018). Understanding perceptions and beliefs about different types of fermented milks through the application of projective techniques: A case study using Haire's shopping list and free word association. Journal of Sensory Studies, 33(12426), 1-8. http://dx.doi.org/10.1111/joss.12326.

Radha Krishnan, K., Babuskin, S., Azhagu Saravana Babu, P., Sasikala, M., Sabina, K., Archana, G., Sivarajan, M., \& Sukumar, M. (2014). Antimicrobial and antioxidant effects of spice extracts on the shelf life extension of raw chicken meat. International Journal of Food Microbiology, 171, 32-40. http://dx.doi.org/10.1016/j. ijfoodmicro.2013.11.011. PMid:24308943.

Rech, R. A. (2010). Produção de salame tipo italiano com teor de sódio reduzido (Dissertação de mestrado). Universidade Federal de Santa Maria, Santa Maria.

SAS Institute. (2009). User's guide statistics. Cary: SAS Institute Inc.

Silva, N., Junqueira, V. C. A., Silveira, N. F. A., Taniwaki, M. H., Santos, R. F. S., \& Gomes, R. A. R. (2010). Manual de métodos de análise microbiológica de alimentos e água. São Paulo: Editora Varela.

Sleder, F., Cardoso, D. A., Savay-da-Silva, L. K., Abreu, J. S., Oliveira, A. C. S., \& Almeida Filho, E. S. (2015). Development and characterization of a tambaqui sausage. Ciência e Agrotecnologia, 39(6), 604-612. http://dx.doi.org/10.1590/S1413-70542015000600007.

Sorensen, G., \& Jorgensen, S. S. A. (1996). Critical examination of some experimental variables in the 2 -thiobarbituric acid (TBA) test for lipid oxidation in meat products. Zeitschrift fur Lebensmittel-Untersuchung und-Forschung, 202, 205-210. http://dx.doi.org/10.1007/BF01263541.
Souza, M. W. S., Ferreira, T. B. O., \& Vieira, I. F. R. (2008). Composição centesimal e propriedades funcionais tecnológicas da farinha da casca do maracujá. Alimentos e Nutrição, 19, 33-36.

Tobin, B. D., O’Sullivan, M. G., Hamill, R. M., \& Kerry, J. P. (2012). Effect of varying salt and fat levels on the sensory and physiochemical quality of frankfurters. Meat Science, 92(4), 659-666. http://dx.doi. org/10.1016/j.meatsci.2012.06.017. PMid:22784420.

Torrico, D. D., Hutchings, S. C., Ha, M., Bittner, E. P., Fuentes, S., Warner, R. D., \& Dunshea, F. R. (2018). Novel techniques to understand consumer responses towards food products: A review with a focus on meat. Meat Science, 144, 30-42. http://dx.doi.org/10.1016/j. meatsci.2018.06.006. PMid:30008336.

Vidal, V. A. S., Biachi, J. P., Paglarini, C. S., Pinton, M. B., Campagnol, P. C. B., Esmerino, E. A., da Cruz, A. G., Morgano, M. A., \& Pollonio, M. A. R. (2019). Reducing 50\% sodium chloride in healthier jerked beef: An efficient design to ensure suitable stability, technological and sensory properties. Meat Science, 152, 49-57. http://dx.doi. org/10.1016/j.meatsci.2019.02.005. PMid:30802818.

Vyncke, W. (1970). Direct determination of the thiobarbituric acid value in trichloracetic acid extracts of fish as a measure of oxidative rancidity. Fette Seifen Anstrichnittel. Leinfelden-Echterdingen, 72, 1084-1087.

Yalinkiliç, B., Kaban, G., \& Kaya, M. (2012). The effects of different levels of orange fiber and fat on microbiological, physical, chemical and sensorial properties of sucuk. Food Microbiology, 29(2), 255259. http://dx.doi.org/10.1016/j.fm.2011.07.013. PMid:22202881. 